\title{
Article
}

\section{Social Work, Power and Performativity}

\author{
Powell, Jason
}

Available at https://clok.uclan.ac.uk/5081/

Powell, Jason orcid iconORCID: 0000-0002-9828-0877 (2012) Social Work,

Power and Performativity. China Journal of Social Work, 5 (1). pp. 67-79. ISSN 1752-5098

It is advisable to refer to the publisher's version if you intend to cite from the work. http://dx.doi.org/10.1080/17525098.2012.656364

For more information about UCLan's research in this area go to http://www.uclan.ac.uk/researchgroups/ and search for < name of research Group>.

For information about Research generally at UCLan please go to http://www.uclan.ac.uk/research/

All outputs in CLoK are protected by Intellectual Property Rights law, including Copyright law. Copyright, IPR and Moral Rights for the works on this site are retained by the individual authors and/or other copyright owners. Terms and conditions for use of this material are defined in the policies page.

\section{CLoK}

Central Lancashire online Knowledge www.clok.uclan.ac.uk

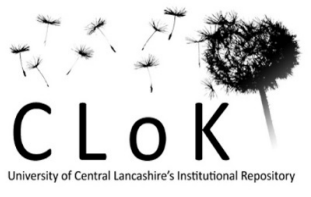




\section{Social Work, Power and Performativity}

\section{Jason L. Powell, University of Central Lancashire, UK}

\section{Introduction}

In the past several decades, helping professions have been variously seen as an economic and moral cornerstone of contemporary societies and, more recently, a self-disciplinary form of governmentality (Powell, 2011). The latter perspective encapsulates a more ambivalent position towards professionalisation, insofar as the privileges and status accorded to professionals are dependent on a form of subjugation and reflexive monitoring (Gilbert, 2001). Reflecting on Judith Butler's conception of 'performativity', it could be argued that the notion has important implications for contemporary debates over agency, subjection and 'resistance' in social work practice. In light of technologies of surveillance and control in contemporary social work, performativity offers a framework towards analysing the production of a subjective space based on trust between social workers and service users (Fleming, 2005). In the USA, England and Australia, the transition from a 'top down' social policy that managed dependent populations through the welfare state's vehicles of pensions, unemployment insurance and healthcare) to a post-welfare or neoliberal politico state has gained momentum in recent years (Gilbert, 2001). In China, economic reform and transition from planned economy to a market economy reconfigures traditional care relationships (Powell, 2011). It can be suggested that social relations in health and social care in China are starting to occur more 'bottom up': central control has been supplemented by local power. Similarly, Chen and Powell (2011) make the claim that the care of older people in China is starting to experience consumer-led models of welfare. Similarly, in the UK, there has seen an increase in the discourses of 'social inclusion' and the current British Prime Minister Cameron's (2011) emphasis on the "Big Society" which is underpinned by a belief that localistic, and not dominant State relationships, are seen as the cornerstone for meeting the care needs of vulnerable people (Powell, 2011). Hence, at the local level in the England, for example, social work is a technology put in place to instigate local relationships of partnership and trust between professionals and older people (Gilbert \& Powell, 2005); a focus on social relationships between professionals and service users. These changes have allowed a social space in which the relations of social workers and clients can illustrate the potential for resistance.

Professionals, such as social workers embedded in discursive institutions function according to particular expectations around performativity. In addition, this organisational context is complex with multiple demands. In such circumstances, social workers adopt different roles depending on function and client group with the consequence that there is always some degree of fluidity and uncertainty around expectations (Whitehead, 1998). This myriad of sites for performativity contains potential for resistance. In addition, performativity does not take place in isolation, nor is the audience one of passive observers. Traditionally, Marxist analysis of social work has 
focused on the domination of clients by social workers (Jones, 1983) based on social class. This 'top down' analysis misses the dynamic relations between social workers and clients. Performance is always relational, drawing others into the act - managers, other professionals, clients - and so constructing both the meanings associated with the performance and mutually dependent subject positions (Wetherell, 2001). Both Giddens (1991) and Mouzelis (1995) suggest there are social conditions that permit the facilitation and constrainment of human action - and it can be said that while performance is relational, it is also complex, indeterminate and open-ended. For example, research in the USA by Callaghan (1989: 192) on the relationship between social work and older people claimed that older people 'were particularly adamant that they did not want to be 'cases' and no-one needed to 'manage' their lives'. However, research by Healy (2001) illustrates that social worker and client relations have centred on resistance to social polarity and have created reciprocal partnerships. Healy (2001) cites partnerships between social work and service user groups in Denmark and Germany in creating better childcare facilities that run counterance to state policies on childcare provision.

This article maps out a consideration of the themes that come to prominence through the juxtaposition of professionalisation and performativity, and what performativity might offer to critical and international studies of helping professions and social work; a phenomenon that can be examined by reference to social work practices such as assessment, child protection, risk management and user involvement.

\section{Performance and performativity}

Through the last 20 years, the work of Judith Butler has had a significant impression on debates over gender and most notably on queer theory, largely in response to her hugely influential Gender Trouble (1990). More recently, her notion of performativity was further delineated in her later works Bodies That Matter (1993) and The Psychic Life of Power (1998a). Her conception of performativity builds primarily on the work of Michel Foucault in particular, developing the twin themes of power as productive and of discourse - or rather, discursive practice - as constitutive of subjects. As she states in Bodies That Matter,

This text accepts as a point of departure Foucault's notion that regulatory power produces the subjects it controls, that power is not only imposed externally but works as the regulatory and normative means by which subjects are formed (Butler, 1993: 22).

While broadly within the Foucauldian tradition, then, Butler attempts to complement and develop this position by drawing on (among other influences) the psychoanalytic influence of Freud and Lacan as well as more diverse work of Searle, Austin and Derrida (1988), amongst others. For many, the key innovation of Butler's view of performativity is her incorporation of linguistic influences, and especially the parallels between Michel Foucault's (1977) subjectification/ subjection, Althusser's interpellation (1971) and the 'speech acts' of Austin (1962) and Searle (1969). Austin in particular distinguishes performative utterances from other speech acts such as denotative (descriptive) or 
prescriptive (command) utterances. As Butler (1993: 225) explains; 'Performative acts are forms of authoritative speech; most performatives, for instance, are statements that, in the uttering, also perform a certain action and exercise a binding power'. The typical examples used, in Austin (1962) as in Butler (1993), are the launch of a ship, wherein the words 'I name this ship...', ... are simultaneously the announcement and description of an act and the act itself. Equally, in other vows, guarantees and other ritualised forms of interaction, the distinction between talk and action is effaced by 'the apparent coincidence of signifying and enacting' (Butler, 1995: 198). As such, this phenomenon offers a useful antidote to the unquestioned oppositions of word and deed, rhetoric and reality, and crucially, discourse and action (Sturdy \& Fleming, 2003).

It is this understanding of performative acts as the elision of discourse and action that suggests relevance for social welfare as more than a mere linguistic curiosity. For Butler, this insight suggests a way in which identity may be similarly seen as constructed in and through action, or performance. In the case of gender, performativity is seen by Butler to offer a non-idealist way to counter the reification of gender stereotypes and denaturalise the status of gender as an ahistorical and universal category. Gregson and Rose summarise (2000: 434) the implications of this position: 'The motivation for this turn would seem to be that to see social identities as performed is to imply that identities are in some sense constructed in and through social action, rather than existing anterior to social processes'. There is a clear link in this formulation to a 'strong' conception of discourse, positing identity as discursively constituted, which treads between the extremes of the social constructivist debate, accounting for both constraint and potential for transformation through discourse. Phillips (2004) and Whitehead (1998) develop further discussions of performativity in terms of gender, this time masculinities.

Thus, Butler is arguing for an 'understanding of performativity not as the act by which a subject brings into being what she/he names but rather as that reiterative power of discourse to produce the phenomena that it regulates and constrains' (Butler, 1993: 2). In doing so, Butler attempts a novel reworking of the tired structure/agency debate and offers a persuasive notion of subjectivity, which is in no way predetermined but is nonetheless 'always already' compromised. Or, as Butler clarifies; 'Social categories signify subordination and existence at once. In other words, within subjection the price of existence is subordination' (Butler, 1998a: 20). Accepting identity as discursively constituted but unpredictable opens this debate to the possibility of multiple identities as individuals, penetrated by an array of discourses, many detached from their traditional moorings; develop selves that are fluid, uneven and unstable. In terms of performativity this unpredictability or 'excess' goes some way towards explaining why actions cannot be determined from social position or professional background alone (Fink, Lewis, Carabine \& Newman, 2004). 'Fluidity, unevenness and instability' create situations where individuals are working to manage tensions and contradictions arising out of their own multiple subject positions. However, these also produce the potential for resistance and the possibility for new subject positions (Whitehead, 1998) thus providing a driving force for change.

An important aspect of Butler's work subsequent to Gender Trouble (Butler, 1990) is to correct the impression that many took from her earlier work that performativity in 
some way reasserted the power of voluntarist action over structural constraint. While the relationship between constraint and individual agency are clearly of concern to Butler, her understanding of this relationship is far more sophisticated than simply adding her weight to the voluntarist side of this tired debate. Instead, Butler's aim is to circumvent the traditional structure-agency debate to avoid becoming 'mired in whether the subject is the condition or the impasse of agency' (1998: 14). With reference to misreadings of her position on gender, for example, she insists that gender is not a simple matter of choice; a garment donned in the morning and discarded in the evening by the sovereign and autonomous individual (Butler, 1993). What is of interest is the power of discourse to construct the subject who makes this 'choice'. Or as she argues elsewhere, 'Power not only acts on a subject but in a transitive sense enacts the subject into being' (Butler, 1997: 13). Her vision of the performativity of gender proposes instead a recursive and reflexive model of identity, where actions are in a sense citations, re-enacting previous performances to claim a certain identity.

Two issues arise from this argument. Firstly, citation sets out a link between performativity and rituals, institutions and ultimately social structures - 'performative utterances' are institutionalised over time and hence become identifiable and carry meaning. Power in this sense loses some of its fluidity forming sediments that 'stick' to certain practices and institutional structures; thus drawing attention to Foucault's (1977) later revisions where he opened the possibility that such structures, while always the outcome and never the origins of power, can nevertheless provide sites for the exercise of power (Beechey \& Donald 1985). Secondly, it is this circular, reiterative aspect to performativity, which provides the space for adaptation and change and by the same token for a practical and pragmatic form of resistance (or perhaps, subversion) discussed elsewhere by Butler (1998b) and Fleming (2005) as cynicism and parody. In addition, it is this latter point on reiteration which best summarises Butler's potential contribution to Foucauldian analyses of helping professions.

\section{Rethinking power and resistance}

The question of resistance in Foucauldian work is a fraught one and lies at the root of what Fleming and Sewell (2002) refer to as 'the Foucault wars' in critical studies of social science (cf. Thompson \& Ackroyd, 1995). Foucault's work has been roundly attacked from various quarters for at best his pessimism regarding the possibility of emancipatory action or at worst, his crypto-conservatism (Dews, 1989; Callinicos, 1990). Even broadly sympathetic writers have noted that in his early work 'despite his assertions to the contrary, Foucault in fact produces a vision of power as a unidirectional, dominatory force which individuals are unable to resist' (McNay, 1992: 40). His later work on 'techniques of the self may be read as an attempt to address this 'missing subject' in his previous work. The enduring relevance of Foucault's work for studies of the workplace lies in his later attempts to rethink resistance outside of an Enlightenment humanist framework, recognising the operation of power in constituting the resistant as well as the docile and industrious subject. If set in the context of the earlier point about multiple subject positions, it becomes possible that the docile, industrious and resistant subject can occur within a single individual providing for very different performances in different areas of 
life; thus bringing into play 'the reflexive self' alongside notions of identity and self-work and the production of the ethical subject (Bernauer \& Mahon 1994). As Foucault (1978: 95-96) emphasises, 'there is no single locus of great Refusal, no soul of revolt, or pure law of the revolutionary... But this does not mean that (resistances) are only a reaction or rebound, forming with respect to the basic domination an underside that is in the end always passive, doomed to perpetual defeat'. The exercise of power is always a product of human interaction and its exercise contains the presumption that subjects may put into effect a degree of freedom, which means that any interaction holds potential for resistance (Powell and Hendricks 2009). Such resistance, where individuals contest meaning and force, provides foundations for creativity exploiting possibilities contained or constrained within that milieu; producing a micro-politics focussed on the immediate concerns of those involved and the emergence of small-scale practical alternatives (Rose 1999). Resistance cannot exist external to human interaction and the power relations this provides. Rouse (1994) describes this mutual dependence as power mediated by 'dynamic social alignments' in a way that has specific implications for our discussion of social work where the maintenance of a relationship is a necessary condition for both reiteration and the space for performativity:

Power is exercised through an agent's actions only to the extent that other agents' actions remain appropriately aligned to them. The actions of dominant agents are therefore constrained by the need to sustain that alignment in the future; but, simultaneously, subordinate agents may seek ways of challenging or evading that alignment. (Rouse 1994:108)

Butler shares this ambivalence over the pervasive nature of power relations in social interaction, seeing them as both potentially dominatory and oppressive but at the same time potentially productive and (for want of a better word) 'empowering'. Against notions of monolithic power as control against individual agency as autonomy, she argues; '... power is not simply what we oppose but also, in a strong sense, what we depend upon for our existence and what we harbour and preserve in the beings that we are' (Butler, 1998a: 2). Thus, the fact that power operates through the production of the subject and through the constitution of agency clearly undermines the perceived 'purity' of resistance: 'resistance is always contaminated by the power it resists' (Fleming, 2005: 53). Yet, this does not imply a nihilistic pessimism:

That agency is implicated in subordination is not the sign of a fatal selfcontradiction at the core of the subject and hence further proof of its pernicious or obsolete character. But neither does it restore a pristine notion of the subject, derived from some classical liberal-humanist formulation, whose agency is always and only opposed to power (Butler, 1998a: 17).

This compromised view of 'agency' certainly calls into question traditional forms of resistance, but also offers a way out of determinism through an emphasis on the iterative nature of subjection; a position bearing resemblance to Miller's (1993) discussion of the self, torn by tensions between personal desire and public obligation that produce an 
'ethical incompleteness' providing the motor for resistance and change. At the same time the 'meaning giving subject' is identified as in-itself a product of discourses of the self (Powell 2011).

Butler's substantive contribution is to build upon this understanding by drawing on work in related areas, particularly by developing a temporal dimension to subjection. The production of the subject is not a one-time condition, a static state but instead should be seen as temporalised, a continual and circular process of sedimentation and congealment, an insight that lends itself well to professional practice, which is less about single statements and their consequent performativity but a process of statement and action. 'Performativity must be understood not as a singular or deliberate "act" but, rather, as the reiterative and citational practice by which discourse produces the effects that it names' (Butler, 1993: 2). As noted, the 'reiterative' or 'citational' aspect of performativity contains within itself the seeds of change and transformation. This 'repetition that is never merely mechanical' (Butler, 1998a: 16) provides the space for divergence, contestation, subversion and ultimately what might be read as resistance. Thus Butler (1998a: 93) argues: 'It is precisely the possibility of a repetition which does not consolidate that dissociated unity, the subject, but which proliferates effects which undermine the force of normalization'. Such performance, in the context of professional practice, generates a very specific form of resistance where repeated performance 'interpreted as experience' produces the possibility of innovatory practice which in departing from agency norms and procedures creates new spaces for autonomy (Gilbert \& Powell, 2005; Powell 2011).

\section{Performativity and professionalisation}

The theme of gender exists as an unspoken referent through Judith Butler's more philosophical works; where she speaks of social categories in a generic sense, gender appears as the archetypal example for the evaluation of the claims she makes. Consequently, the question presents itself whether Butler's analysis may be extended to discourses, which are less 'pervasive' and 'central' to social interaction than gender. More simply, can we legitimately lift concepts from the performance of gender and use them to understand what might be seen as more 'central' aspects of subjectification, such as professional identity. Schryer and Spoel (2005: 250), using the concept of genre as forms of social action, explore the significance of performativity to gaining membership of professions. Highlighting the internal resources of particular genre, they identify an internal structure established by two elements: regulated resources, which refer to knowledge, skills and language behaviours, required by a profession; and regularized resources, i.e. behaviours that are tacit, emerging from practice-based situations.

Genres are the product of embedded social practices (e.g. health or social policy, theories of social work practice) with professions drawing on these in the construction of their identity. Communicative interaction between individuals and organisations provides circumstances where the co-constitution of texts and contexts takes place. What is more, genres compete in a complex matrix of power relationships seeking to regulate other genres. For example, Milner and O’Byrne (1998) identify the new climate for social work of empowerment, choice, partnership and value for money, thus moving towards what 
Foucault (1972) described as the 'orders of discourse', the specific localised organisation of discourses providing the discursive structure of an organisation or similar language based institution (Fairclough, 1992). Providing a dynamic that undermines notions of stability in either individual or collective identity thus creates space for improvisation, or what Thompson (2000) describes elsewhere as discretion, as situations and contexts change, and as a consequence the potential for resistance and the emergence of new subject positions. Alongside Judith Butler's notion of repetition, discretion provides further spaces in which inventiveness and creativity in professional practice can occur and where bureaucratic norms are challenged and rendered obsolete.

A Foucauldian approach to professionalism (e.g. Fournier, 1999; Grey, 1998) attempts to integrate the micro-political tactics of professionalisation with broader power relations through the analysis of discourse and regimes of power/knowledge. As Fournier argues (1999), while the legitimacy of the professions relies upon the establishment and maintenance of appropriate norms of knowledge and conduct, which includes adherence to changing political imperatives (Johnson, 2001), such norms also act as a form of discipline over otherwise autonomous professional power. Thus, induction into professions, in terms of both knowledge and conduct, serves to construct a specifically governable subjectivity rooted in self-disciplinary mechanisms (Gilbert, 2001; Grey, 1998). The situation is summarised succinctly by Fournier (1999: 285), who states, 'Professionals are both the instrument and the subject of government, the governor and the governed'. Paradoxically, professional autonomy, particularly in areas such as social work, is both the reason why the professions remain necessary due to their ability to employ discretion to manage complex and unpredictable situations while also providing the focus for the deployment of a range of disciplinary technologies as the state acts to limit and constrain the exercise of that autonomy (Clarke \& Newman 1997; Powell and Hendricks 2009). Procedural arrangements identified within social policies such as 'Every Child Matters'(Department of Health, 2004), and Independence, Well Being and Choice' (Department of Health, 2005) and then operationalised through a myriad of statutory and independent sector agencies lay down conventions upon which performativity takes place; in so doing demonstrating both the productive and disciplinary effects of power.

This view of professionalisation as a mode of disciplinary control also provides a useful counterbalance to critical perspectives, which reinforce the stereotypes of pampered and privileged professionalism. In recasting professionalism as a source of influence and status concomitant with self-discipline and controlled performance, the Foucauldian position also links professionalisation with a wider range of control strategies based on the manipulation of identity, such as corporate culture initiatives (Dyer \& Keller-Cohen, 2000; Fleming, 2005; Hochschild, 1983; Whitehead, 1998). In the context of the caring professions, these strategies place professional expertise at the heart of disciplinary technologies designed for management of populations. Operating through organisations (discursive institutions) increasingly dispersed across the independent and voluntary sectors (Clarke \& Newman, 1997), professional status and expertise is located with embedded social practices and specific forms of performativity concerned with the identification and management of risk (Petersen, 1997; Powell, 2011; Rose, 1996, 1999; Taylor-Gooby, 2000; Turner, 1997). These performances construct professionals as 
subjects, subjectified within an array of often contradictory discursive formations (e.g. care, social control, enabling, empowering, deserving, undeserving) while simultaneously producing the targets of their performance, 'clients or service users, as both subject and object.

\section{'A professional performance': social work, knowledge and subjection}

Drawing on Foucauldian positions on professionalism, it can be argued that an essential part of the professionalisation project involves the constitution and operation of social work as a discipline. Clearly, this discipline does not exist merely in some abstract, ideal form; rather, discipline should be seen as inscribed in texts, practices, technology, performances and crucially in the subjectivities of those individuals instructed in the discipline. What is challenging is that individual social workers take on different roles in different contexts and therefore potentially different, possibly competing, subjectivities. For example, Independence, Well-Being and Choice (2005) identifies four roles for social workers: assessing needs, developing constructive relationships, assessing risks to individuals and risks to communities, encompassing a range of activity including individual facework with individuals and groups, interprofessional collaboration and multi-agency and partnership working. Further complications arise when we acknowledge the range of organisations employing social workers in the statutory and independent sector, which brings into play a complex range of different procedural commitments and associated genre, which in turn provide scripts or texts supporting performativity in relation to a complex array of activities. These activities include: identifying children 'at risk' in child protection procedures; applying the provisions of mental health legislation when compulsory detaining individuals; assigning a 'risk' status to individuals or families following risk assessment in areas such as 'vulnerable adults' (Department of Health/Home Office, 2000) and domestic violence (Mullender \& Hague, 2005); or ascribing the status of 'deserving' or 'undeserving' when considering support. All these activities involve statements either verbalised and/or written which when enacted by social workers perform particular actions underpinned by particular configurations of knowledge and power.

To understand the production of subject positions through the professionalisation discourse, it is useful to draw on Butler's reading of Althusserian interpellation. The core of professionalism, as noted earlier, is what is termed 'professional spirit'. A parallel can be drawn here between professional spirit and, in Althusser's terms, the conscience of the good citizen. As Butler (1998a: 115) argues, 'Conscience is fundamental to the production and regulation of the citizen-subject, for conscience turns the individual around, makes $\mathrm{him} /$ her available to the subjectivating reprimand'. Similarities are apparent here with Miller's (1993) discussion of 'ethical incompleteness' which produces the 'reflective self' that drives the post-modern citizen towards self-improvement and self-management, and Gilbert's (2001) later exploration of 'reflective practice' in professions as a confessional technique deployed as surveillance.

At this point, it would be useful to return briefly to Austin's (1962) discussion of performatives. The nature of a performative means that it is not possible to identify it as 
true or false however, performatives can be infelicitous to which Austin provides particular conditions upon which felicity is established:

a i) There must be an accepted conventional procedure having a conventional effect, and further,

a ii) The particular persons and circumstances in a given case must be appropriate for the invocation of the particular procedure.

b) The procedure must be executed by all participants both (i) correctly and (ii) completely.

c) often, (i) the persons must have certain thoughts, intensions, etc. which are specified in the procedure, (ii) the procedure specifies certain conduct which must be adhered to. (Potter, 2001: 44)

The significance is that workers in caring professions such as social workers meet these conditions in a range of circumstances, a number of which were noted earlier. In general, social workers follow specific professional or agency procedures for a defined outcome (condition (a)): individual social workers must have the seniority or authorisation to carry out the procedure (condition (b)); actions initiated by the social worker have to fulfil the procedural requirements and the requirements of professional practice in full (condition (c)); and; values and attitudes, e.g. anti-oppressive practice, have to be displayed throughout the process (condition ( $\mathrm{d}$ i \& ii)). What is not so clear from Austin's conditions is that performance with respect to these procedures is always relational requiring the involvement of fellow performers. These 'fellow performers' may be supportive, e.g. other professionals drawn on to provide expert opinion; or antagonistic, e.g. professional or lay advocates. At the same time, there will be the focus of the performance, e.g. the individual, group or community that needs working on whose reciprocal performance may create tensions and contradictions, to which social workers have to respond in their performance, thus providing a degree of uncertainty. Another, somewhat ambiguous set of performers is also on hand, not always active, but never passive, representing the range of offices that supervise or monitor performance. Some represent the organisations involved while others monitor performances within these organisations. Collectively, performativity produces the identities of those involved defined in relation to others (Forbat \& Atkinson, 2005; Miehis \& Moffatt, 2000; Payne, 2004). By their very performance, social workers also create as 'other' (Hall, 2001) the target of their work.

Taking Schryer and Spoel's (2005) discussion of genre as social action, regulated resources link with external demands, in this instance the procedural requirements demanded by contracts, social policy and professional bodies. Outcome orientated, these procedural requirements produce the target of performativity, the social work client' as 'object'. Risk management, child protection and procedures linked to detention under mental health legislation all seek to manage external expectations while also providing for the objectification of individuals or groups and the satisfaction of managerial and bureaucratic imperatives (Powell, 2011). Regularised resources, arising from practice and facework are process orientated and produce the 'client' as subject. The genre creates space for performativity, shaping the identities of participants as subjects while subjugating that identity within the communicative structure of organisations. Possibly 
the most striking example of this space for performativity takes place within the context of user and carer involvement which has a central role in both contemporary social work practice and in the operation of social work and social care agencies (Beresford, Croft, Evans \& Harding, 1997; Department of Health, 2006). In this context, performativity creates very specific spaces where statements underpinned by a value base of participation coincide with actions that are both the act of inclusion and the exercise of knowledge/power. However, these spaces are also unpredictable as they provide space for what Foucault (1984) describes as subjugated or discredited knowledges of the marginalised containing the potential for what Butler (1998) identifies as 'divergence, contestation, subversion and resistance'.

Performativity also provides a basis for analysing the complexity of professional practice where a single practitioner undertakes different roles, often with different value bases, in different contexts. A particular example of this dilemma is evident in social work assessment. A number of writers (Milner \& O’Byrne, 1998; Smale, Tuson \& Statham, 2000) describe three models of social work assessment - the Questioning, Procedural and Exchange models - each positioning the social worker differently in relation to the client, the organisation and the social context. Linking with the discussion above, Questioning and Procedural models represent a particular genre while the Exchange model provides an alternative genre that shares some of the same discursive structure but which also differs in important ways. In short, the Questioning and Procedural models place the professional as expert, the organisation as authoritative, wants are distinguished from needs which are defined a priori, outcomes are privileged and the client/service user is passive and dependent. Exchange models structure a different relationship; the client/service user is expert in relation to their social circumstances, the social worker expert in working collaboratively, the focus is on process (engagement and negotiation) as much as outcome, oppressive social contexts are acknowledged, existing strengths used to identify needs, and the user is active and enabled. Each model expects performativity consistent with the genre, Austin's (1962) conditions of felicity, suggesting that social workers adapt their particular performances to suit different genre. Alternatively, each might provide the basis for subversion and resistance through contaminated by an alternative genre.

Taking a somewhat different trajectory, Sheppard (1995) explores professional identity and status through the relationship between the social sciences and professional practice. Successful, high status professions, such as medicine are those that have managed the balance between technicality and indeterminacy: a balance between rule-based actions and the exercise of discretion, where high technicality provides the opportunity for managerial control while increasing indeterminacy undermines claims for a distinct knowledge base and professional education (Powell and Hendricks 2009). Sheppard reviews the influence of social science knowledge on social work practice identifying an awkward relationship however; he advocates social science method, analytic induction, as a model for good practice. This specific genre demonstrates the reiterative or citational nature of performativity (Butler 1993, 1998) while also providing the base for a particular performativity which in effect, gives dominance to the regularised, i.e. practice-based processes, over regulated, i.e. procedural-based processes, in defining social work as a 
profession. Discursive spaces that produce professional identity and resistance occur, therefore, through practice-based relationships rather than within procedures.

These spaces may have a further relevance to this discussion. Hendricks and Powell (2009) exploring resistance to managerialism in general and more specifically identity-based controls in contemporary post-industrial workplaces, suggests that actions such as cynicism, irony, humour and scepticism, once seen as a defence of selfhood, provide a more important function as they create a subjective space through which selfhood is produced. Coupled with this, Fleming (2005) draws on Butler's (1998b: 34) notion of cynical parody to make the point:

...parody requires a certain ability to identify, approximate, and draw near; it engages an intimacy with the position it approximates that troubles the voice the bearing, the performativity of the subject...

Thus providing the possibility of alternative performances within the same genre, one performance complies with procedural requirements while a second performance opens space for the production of a resistant self, providing a degree of stability in contexts of instability, flux and discontinuous change, in the sense that one might, on the one hand, be the consummate professional social worker, while, on the other, a radical political activist.

\section{Conclusion}

Performativity offers productive insights into the processes of subjection and the nature of power relations, which may be usefully incorporated into debates about subjectivity, resistance and agency. As Healy (2001) suggests, international debates on social work have centred on the partnerships between social workers and client groups to resist and pressure governmental policy on childcare. For example, Healy cites social workers in Jamaica organising partnership social work-client coalition on the 'Rights of the Child' as a report on Jamaica's progress on protecting children to the United Nations Centre for Human Rights in Geneva. In addition, in England, Mullender and Hague (2005) describe how recognition as a user group through a social worker/user partnership enabled participation by women experiencing domestic violence. Among the various strengths of the concept, performativity offers a more sophisticated understanding of agency which fully embraces the complex and problematic nature of power relations; it breaks down realist distinctions between discourse and action through a palpable sense of the constitutive power of discourse; it suggests a view of subjection which is processual and temporal, rather than fixed and predetermined; and perhaps most importantly, we would argue that performativity, in all of these ways, combats the lazy categorisation of Foucauldian work as fundamentally conservative and reactionary, erasing the possibility of effective resistance from the intellectual landscape.

It is therefore in an attempt to explore these aspects that performativity has been used to reappraise issues of power, control, subjection and resistance in the context of professionalisation in social work and social welfare. Performativity also connects with work on professionalism as a performance, and incorporates much older debates over authenticity, and the relations between subjectivity and conduct. (Goffman, 1959). In the 
first instance, then, such a perspective underlines the view of professionalism as always enacted and performed - a processual and temporal phenomenon. The understanding of professionalisation as a mode of subjection, involving both subordination and security, dependence and power, but in no sense deterministic or debilitating, a position with significant potential for understanding contemporary social work.

\section{References}

Althusser, L. (1971) 'Ideology and Ideological Apparatuses (Notes towards an Investigation)' (reprinted). In Subjectivity and Social Relations (1985) Beechey, V. and Donald, J. eds. Milton Keynes. Open University Press

Austin, J.L. (1962) How To Do Things With Words Oxford. Oxford University Press Beechey, V., \& Donald, J. (1985) Introduction, in Subjectivity and Social Relations (1985)

Beechey, V. and Donald, J., eds. Milton Keynes. Open University Press

Beresford, P., Croft, S., Evans, C. and Harding, T. (1997). Quality in personal social services: The developing role of user involvement in the U.K. In A, Evers., R, Haverinen., K, Leichsenring and G, Winstow. eds. Developing Quality in Personal Social Services: A European Perspective. Aldershot. Ashgate.

Bernauer, J, W., \& Mahon, M. (1994) The Ethics of Michel Foucault, in Gutting, G. ed. the Cambridge Companion to Foucault. Cambridge. Cambridge University Press Butler, J. (1990) Gender Trouble: Feminism and the Subversion of Identity London. Routledge

Butler, J. (1993) Bodies That Matter: On the discursive limits of 'Sex' London. Routledge Butler, J. (1995) “Burning Acts, Injurious Speech", Performativity and Performance Parker, A. and Sedgwick, E.K. London. Routledge 
Butler, J. (1998a) The Psychic Life of Power: Theories in subjection Stanford, CA. Stanford University Press

Butler, J. (1998b). Merely Cultural, New Left Review, 227: 33 - 34

Callaghan, J (1989) 'Case management for the elderly; a panacea?' in Journal of Aging and Social Policy, 1, 2: 181-195.

Callinicos, A. (1990) Against Post-modernism London: Polity Press

Casey, C. (1995) Work, Self and Society: After Industrialism London. Routledge

Chen, S. and Powell, J.L. (2011) Aging in Perspective and the Case of China: Issues and Approaches New York: Nova Science

Clarke J. \& Newman J. (1997). The Managerial State. London: Sage.

Cohen, L. Finn, R. Wilkinson, A. and Arnold, J. (2003) 'Preface: Professional Work and Management' in International Studies of Management and Organization 32(2): 3-24

Dean, M. (1994). “A social structure of many souls”: Moral regulation, government and self-formation. Canadian Journal of Sociology. 19: 145-168

Department of Health (2000), No Secrets: Guidance on Developing and Implementing Multi-Agency Policies and Procedures to Protect Vulnerable Adults from Abuse. London. Department of Health.

Department of Health (2004) Every Child Matters: Change for Children, London. The Stationery Office

Department of Health (2005) Independence, Well-being and Choice, Cm 6499, London. The Stationery Office. 
Department of Health (2006) Reward and recognition: the principles and practice of service user payment and reimbursement in health and social care: a guide for service providers, service users and carers. London. The Stationery Office.

Derrida, J. (1988) 'Signature, Event, Context', Limited, Inc. Evanston. North Western University Press

Dews, P. (1989) 'The Return of the Subject in Late Foucault', Radical Philosophy Vol. 51 pp. 37-41

Durkheim, E (1957) Professional Ethics and Civic Morals London. Routledge Dyer, J., \& Keller-Cohen, D. (2000). The discursive construction of professional selves through narratives of personal experience, Discourse Studies, 2(3): 283 - 304 Fairclough, N. (1992) Discourse and Social Change, Cambridge. Polity Press.

Fink, J., Lewis, G., Carabine, J. \& Newman, J. (2004) Personal Lives and Social Policy: course companion. London. Sage

Fleming, P. (2005) Metaphors of Resistance, Management Communication Quarterly, 19(1): $45-66$.

Fleming, P. and Sewell, G. (2002) 'Looking for the Good Soldier, Svejk; Alternative Modalities of Resistance in the Contemporary Workplace', Sociology 36 (4): 857-872 Forbat, L., \& Atkinson, D. (2005) Advocacy in Practice: The troubled position of advocates in adult services. British Journal of Social Work, 35: 321 - 335

Foucault, M (1972) The Archaeology of Knowledge. London. Tavistock.

Foucault, M. (1978) The History of Sexuality: An Introduction Harmondsworth. Penguin 
Foucault, M. (1984) Space, Knowledge, Power. In P, Rabinow. ed. The Foucault Reader. Harmondsworth. Penguin.

Fournier, V. (1999) 'The Appeal to `Professionalism' as a Disciplinary Mechanism', The Sociological Review 47 (2): 280-307

Freidson, E. (1970) Professional Dominance: The Social Structure of Medical Care Chicago. Atherton Press

Gilbert T. (2001) Reflective practice and clinical supervision: meticulous rituals of the confessional. Journal of Advanced Nursing 36(2): 199-205.

Gilbert, T and Powell, JL. (2005) 'Family, Caring and Aging in the UK', Scandinavian Journal of Caring Sciences, 41, (2): 41-48

Giddens, A. (1991) The Consequences of Modernity, Cambridge. Polity:

Goffman, E. (1959) The Presentation of Self in Everyday Life Harmondsworth. Penguin Gregson, N. and Rose, G. (2000) "Taking Butler Elsewhere: Performativities, Spatialities and Subjectivities", Environment and Planning D: Society and Space 18 (4): 433-52 Grey, C. (1998) ‘On Being A Professional In A ‘Big Six’ Firm’, Accounting, Organizations and Society 23 (5-6): 569-587

Hall, S. (2001) The Spectacle of the Other. In Wetherell, M., Taylor, S., \& Yates, S, J., [eds.] Discourse Theory and Practice, London. Sage.

Healy, L (2001) International Social Work: Professional Action in a Interdependent World, OUP. London

Hochschild, AR. (1983) The Managed Heart: The Commercialization of Human Feeling London. University of California Press 
Jones, C. (1983) State Social Work and Capitalism and the Working Class, London.

Macmillan

Lyotard, JF. (1984) The Postmodern Condition, Manchester University Press. Manchester

McNay, L. (1992) Foucault and Feminism: Power, Gender and the Self Cambridge. Polity

Press

Miehis, D,. \& Moffatt, K. (2000) Constructing Social Work Identity Based on the Reflexive

Self. British Journal of Social Work, 30: 339 - 348

Miller, T. (1993). The Well-Tempered Self: Citizenship, Culture and the Postmodern Subject. John Hopkins University Press. Baltimore

Milner, J., \& O’Byrne, P. (1998) Assessment in Social Work. Basingstoke. MacMillan

Morris, PWG. (1997) The Management of Projects London. Thomas Telford

Mouzelis, N. (1995) Sociological Theory : What Went Wrong? Diagnosis and Remedies.

London. Routledge.

Mullender, A. \& Hague, G. (2005) Giving voice to women survivors of domestic violence through recognition as a service user group. British Journal of Social Work, 35(8): 1321 -

1341

Parsons, T. (1954) 'The Professions and Social Structure’ Essays in Sociological Theory

New York. Free Press

Payne, M. (2004) Social Work Practice Identities: An Agency study of a Hospice, 16(1): 5 15

Petersen A. (1997). Risk, governance and the new public health. In Petersen A. \& Bunton R. eds. Foucault: Health and Medicine. London. Routledge, pp 189 - 206

Phillips, DA., (2004) Reproducing normative and marginalised masculinities: adolescent male popularity and the outcast. Nursing Inquiry, 12(3): 219230 
Potter, J. (2001) Wittgenstein and Austin. In Wetherell, M., Taylor, S., \& Yates, S, J., [eds.] Discourse Theory and Practice, London. Sage

Powell, J. (2011) Aging and Social Policy; A Foucauldian Excursion, New York: Nova Science

Powell, J. and Hendricks, J (Eds.) (2009) The Welfare State in Post-Industrial Society, New York: Springer Verlag

Rose N. (1996). The death of the social? Re-figuring the territory of government.

Economy and Society. 25(3):327-356.

Rose N (1999). Powers of Freedom: Reframing political thought. Cambridge. Cambridge University Press.

Rouse, J. (1994) Power/Knowledge, in G, Gutting [ed.] The Cambridge Companion to Foucault. Cambridge. Cambridge University Press.

Schryer, CF., \& Spoel, P. (2005). Genre Theory, Health-Care Discourse, and Professional Identity Formation, Journal of Business and Technical communication, 19(3): 249 - 278 Searle, JH. (1969) Speech Acts: An Essay in the Philosophy of Language London.

Cambridge University Press

Sheppard, M. (1995) Social work, Social Science and Practice Wisdom, British Journal of Social Work, 25: 265 - 293

Smale, G., Tuson, G., \& Statham, D. (2000) Social Work and Social Problems, Basingstoke. MacMillan. 
Sturdy, A. and Fleming, P. (2003) 'Talk as Technique - A Critique of the Words and Deeds Distinction in the Diffusion of Customer Service Cultures in Call Centres' Journal of Management Studies 40(4) pp. 753-774

Taylor-Gooby P (2000) Risk and Welfare. In Taylor-Gooby P ed. Risk, Trust and Welfare. Basingstoke. MacMillan, pp $1-20$.

Thompson, P. and Ackroyd, S. (1995) 'All Quiet on the Workplace Front? A Critique of Recent Trends in British Industrial Sociology', Sociology 29(4): 615-633

Thompson, N. (2000) Understanding Social Work: Preparing for practice, Basingstoke. MacMillan

Turner BS. (1997). From governmentality to risk: Some reflections on Foucault's contribution to medical sociology. In Petersen A. \& Bunton R. eds. Foucault: Health and Medicine. London. Routledge, pp ix - xxii.

Wetherell, M. (2001) Themes in Discourse Research. In Wetherell, M., Taylor, S., \& Yates, S, J., eds. Discourse Theory and Practice, London: Sage

Whitehead, S., (1998) Disrupted Selves: resistance and identity work in the managerial arena, Gender and Education, 10(2): 199 - 215 